\title{
On Staging in the Loess Formation of Siberia
}

\section{Igor Noskov', Sergey Ananyev', Vladimir Lyutov $^{1}$ Andrei Sviderskikh², Andrei Surtaev ${ }^{1}$ \\ ${ }^{1}$ Polzunov Altai State Technical University, 46-Pr. Lenina, Barnaul, Russia, 656038 \\ ${ }^{2}$ LLC Barnaul branch of Sibirskaya Teplosbytovaya Kompaniya, 36-Gogol Str., Of. 210B, Barnaul, The Altai Territory, Russia, 656056}

Key words: Loams, Marls, Diagenetic Processes, Pleistocene

Study area: Siberia

Coordinate: $60^{\circ} \mathrm{o}^{\prime} \mathrm{N} 105^{\circ} \mathrm{o}^{\prime} \mathrm{E}$

\section{Abstract}

A generalized analysis of the staging of the loess formation in Siberia is presented, where the rocks reveal a different genesis. It has been established that the formation of loess is a geochemical process, expressed in the loessivation of fine-grained sediments and proceeding under certain physiographic conditions. The intensive development of eluvial weathering processes, soil formation, the predominance of evaporation over precipitation are associated with the same. In addition, it has been established that loess is the most dynamic and unstable system in which its constituent elements- mineral and particle size distribution, exchange bases, humidity, structure are in constant and continuous communication with the surrounding physiographic environment. The final development phase of such a system in the cycle of sedimentary rocks formation are dense calcareous loam, clay, marlite, marl. The composition and properties of loess rocks are most susceptible to changes over time and thus they are not found in sediments older than the lower Pleistocene.

\section{Introduction:}

Quaternary covers, represented by loess rocks, occupy the vast spaces of the southern and mid-latitude regions of Siberia and the Far East. They were formed in anthropogen (human emerge), mainly in the middle and upper Pleistocene. Loess formation in Siberia continues in the present geological epoch. Being subaerial continental rocks of the residual soil zone and soil formation processes, the loess soil has a different genesis. In terms of particle size, they belong to silty loam and sandy loams and are distinguished by a special structure that is unique to them. Dust particles $\left(0.005^{-0.05} \mathrm{~mm}\right)$ predominate in their composition, and clay particles $(<0.005 \mathrm{~mm})$ usually contain less than $30 \%$. The loess porosity is more than $40 \%$ of the total volume, the canaliculi are visible to the naked eye. A characteristic feature of these rocks is their calcareousness, micro-aggregation, and macroporosity.

As per lithological characteristics, loess rocks can be divided into the loess, loess loam, and sandy loam. Loess differ from loess-like rocks as they are more homogeneous in grain size, contain from 30 to $55 \%$ of particles $0.01-0.05$ $\mathrm{mm}$ in size, non-layered, yellowish-gray (pale-yellow), have a high (> 46\%) porosity (with the presence of macropores), strongly sagging, without lenses of sand, gravel and pebble, are capable of forming vertical slopes (Uhov et al., 2002).
At present, it is generally accepted that the fine soil from which the loess rocks are formed can accumulate in different ways: eluvial, diluvial, proluvial, alluvial, aeolian and fluvioglacial (Yurchenko \& Budikova, 2008).

But it is not the method of transfer of fine-grained material that forms the loess rock, but the processes that prepare the fine soil in weathering areas and the processes occurring in the accumulation areas that turn the accumulated sediment into loess rock with a specific structure and other characteristics for this rock properties. Gravity, air or water flow forces move fine-grained weathering products to the sediment accumulation area, but rock, which is loess and loess loam, is formed only during sediment accumulation and further diagnosis. The aggregating and coagulating action of clay and carbonate solutions of calcium and magnesium acts major role in it.

\section{Modern concept on Loess formation:}

Modern studies show that loess can be formed from any carbonate fine-grained rock after its deposition or, partially, in the process of deposition in the arid steppe climate, due to the processes of weathering and soil formation (Yurchenko \& Budikova, 2008). In addition, it is believed that the fine-earth carbonate mass, which has the main properties of loess, is prepared by weathering

*Corresponding Author: gluk_cs@mail.ru 
processes in areas of demolition before sediment formation, and only some of these properties arise in the process of sedimentation or further diagenesis (Yurchenko \& Budikova, 2008). We discussed here the formation of loess rocks and their existence in geological time on the example of loess rocks of Western Siberia, the material composition, structure, origin, and stratigraphy of which are devoted to a lot of research by Polzunov Altai State Technical University.

The formation of subaerial sedimentary rock begins with the accumulation of detrital material, the chemicalmineralogical and mechanical composition of which later changes somewhat in the process of establishing the physicochemical equilibrium between the components of the sediment and the environment (Efimova et al., 2003). In the primary sedimentary mineral mass, new, secondary mineral formations appear, resulting from postgenetic processes (Efimova et al., 2003). Loesses, like sedimentary rocks, are subject to the same patterns of formation and differ from other detrital sedimentary rocks only by the most unstable form of fine soil, partial aggregation of clay and silt fractions and structure, whose existence is very limited both in time and in space (Spassov et al., 2003). The thin-clay, colloidal part of the rock, changing the composition of the absorbed cations and the degree of saturation with them, is particularly variable. Fine soil sediment, whatever its origin, including eolian, is not a loess rock, unless it has not acquired a certain structure inherent to loess. Even the redeposited by one or other denudation agents, prepared by weathering and sufficiently aggregated fine-soil carbonate material does not possess all the features of the loess rock structure. This structure is little stable in geological time and we do not know loess rocks older than the beginning of the Pleistocene.

\section{Earlier reports:}

The stratigraphy and paleogeography of the Quaternary period of Western Siberia have been studied well enough to talk about the time and conditions of the loess formation occurring in the Pleistocene lowland sections.

In the southern regions of the West Siberian Lowland, beyond the maximum Samarovsky glaciation, there are two major stages in the formation of subaerial loess rocks, the metachronicity in the formation of which indicates the influence of local conditions on the loess covers development (Yurchenko \& Budikova, 2008). The first stage is associated with the accumulation of the Krasnodubrovinskaya suite (Q2t - Q2sm), the lower mass of which (Q2t) in the sections of the Steppe Plateau begins with coarse-grained sandy sediments of periodic small water streams, cones, river deltas and drying small lakes. The roof of this mass is represented by a pack of subaerial loess like loams with 3-5 horizons of buried soils (Spassov et al., 2003). Palynological data allow us to consider the climate of the formation time of the lower alluvial pack warm and dry, characteristic for the southern steppes.

The upper mass (Q2sm) of the Krasnodubrovinskaya suite is composed of horizontally layered loess like sandy loams and less like loams, with traces of cryoturbations and exogenous processes of cold dry semi-desert. According to the facial features, these sediments can be attributed to aeolian, to the sediments of drying out lakes, temporary streams, and proluvial exhaust cones (Zhou \& Shackleton, 1989).

Apparently, sediments accumulation has repeatedly interrupted, as evidenced by the horizons of buried soils found among loess. In the final stage of maximum glaciation in the extra glacial area, a complex system of powerful meltwater flows of the Altai mountain glaciers from the south and of the glaciers from the north appeared. Tavda, Vasyugane, Narym, Baraba, Kulunda, Tym-Ket plain became periglapalpy areas of accumulation of fine soil sediments and their hypergenesis (Uhov et al., 2002).

The second stage of the loess formation in Siberia captures a long period of time, associating with the Zyryan glaciation (Q2zr). According to numerous paleogeographic studies, loess rocks of Siberia were formed in dry and rather cool steppe conditions (Uhov et al., 2002). Any climate change in the direction of increasing humidity caused a break in forest formation, and arid conditions were a constant factor in the transformation of fine-soil sediments, accumulating in the cover, into loess rocks (Efimova et al., 2003).

Loess formation is a geochemical process, expressed in loessivation of fine-grained sediments and proceeding under certain physiographic conditions. The intensive development of eluvial weathering processes, soil formation, the predominance of evaporation over precipitation are some of them (Efimova et al., 2003). A newly deposited diluvial, proluvial, alluvial or aeolian finegrained sediment is exposed to air, sharp fluctuations in temperature, precipitation, flora, and fauna. All these factors modify the subaerial sediments and form the loess rock. Therefore, the processes of loessivation should be attributed to early diagenesis.

\section{Stages identified for loess formation}

Three stages can be distinguished in the formation of loess rocks (Zhou \& Shackleton, 1999):

i)- accumulation of fine-grained sediment and its weak, diagenetic processing;

ii)- loessivation of fine-grained sediment, acquisition of loess structure, loess qualities;

iii)- degradation of the loess features of the rock and its transformation into dense calcareous loams, clays, marls, marlites.

The first stage should be referred as syngenetic since it includes the processes of sedimentation storage and formation of particle-size distribution, the processes 


\section{GENERAL ARTICLE}

occurring in the uppermost part of the sediment in the initial period of its existence before it turns into a loess rock. The syngenetic stage develops simultaneously with accumulation of aeolian, eluvial and deluvial sediments, as well as during the initial period of draining of proluvial, alluvial and fluvioglacial sediments (Spassov et al., 2003). In the latter case, this stage is especially characteristic for the sediment of wandering streams of melt glacial water under conditions of periodic frost chilling of wastewater. The sediments in this initial period remain very loose. The coagulation of flocculent suspensions proceeds under the influence of electrolytes, due to which this process in alluvial, lake and proluvial sediments begins long before they are drained (Zhou \& Shackleton, 1999). In river water, especially during spring, when the water remains most fresh, suspensions of mineral and organic substances are differentiated by size with orthokinetic coagulation occurrence.

The sediments in this stage are well drained and often washed. Under such conditions, cations of alkaline and alkaline-soil elements are easily leached and removed from the sediment with water, which slows down or even retards the formation of its cementation structures.

The Upper Priobye in the middle and upper Pleistocene, as well as at the beginning of the Holocene, was characterized by a cold climate, therefore the ground and pore water of the overburden was often frozen. During the formation of loess rocks of Siberia, frosty weathering apparently prevailed over other types of weathering. Consequently, along with the processes of gravitational sorting of sediments of transport, the leading role in the formation of the granulometric composition of the future loess rock belongs to the frosty weathering; temperature drops through zero, freezing of water in microcracks leads to crushing, the disintegration of part of rocks and constituent minerals (Efimova et al., 2003).

Weathering of parent rocks in the specific conditions of the era of loess formation leads mainly to the physical fragmentation of their minerals. The limiting particle size, on reaching which further grinding of grains during physical weathering occurs very slowly, is about $0.01 \mathrm{~mm}$ (Yurchenko \& Budikova, 2008). This is explained, on the one hand, by the fact that, with such a grain size, they are not enriched by corrosion during wind and water erosion, on the other hand, by the fact that the intensity of frost cracking of the grains decreases as they are crushed due to a decrease in the freezing point of water in thin films. As a result of weathering, fine-grained eluvial rock is formed with a particle size close to loess. At the same time, chemical weathering lies in the formation of hypergenic syngenetic clay minerals from the montmorillonite and hydromica group, as well as carbonates. An example of this is weathering of shale near Novosibirsk (Spassov et al., 2003). The clay-wood eluvium of shale, which is formed
Ambient Science, 2019: Vol. 06(1); 01-06 DOI:10.21276/ambi.2019.06.2.ga01

during physical weathering, undergoes weak hydration and oxidation with the formation of ferum hydroxides. Further chemical weathering of sericite and chlorite increases the clay content of the precipitate. Calcium carbonates in easily soluble bicarbonate form are formed in the largest amounts in the weathering zone in the cold climate. And this apparently explains the existence of young and modern loess rocks in the north of Western Siberia in Yakutia (Uhov .et al., 2003).

The medium under these conditions is usually acidic, the $\mathrm{pH}$ value is less than 7.2 ; the processes of kaolinite formation are developing, which leads to an increase in the amount of this mineral in the sediment (Yurchenko \& Budikova, 2008).

\section{Geochemical analysis of the formations:}

Microscopic studies of fresh clay sheet of terraces and modern eolian drift of the Novosibirsk region and Altai Territory showed that these deposits consist not only the fragments of mineral grains, but in large part of their dust and sand fractions are represented by complex polymineral aggregates (Spassov et al., 2003). Consequently, these units are re-deposited again or formed in the area of weathering and demolition, or formed along the path of transfer of fine-grained material.

The cause of the clay-aleurite aggregates should be evaluated under the special physico-chemical characteristics of clay minerals. In the tetrahedral system of the structure of clay minerals, an isomorphic replacement of Si by Al occurs, and in the octahedral system, there is a replacement of $\mathrm{Al}$ by $\mathrm{Mg}$ and $\mathrm{Fe}$, while in the replacement areas the negative charge is released (Efimova et al., 2003). As a result, it becomes possible to adsorb clay matter from the environment through the electrical forces of one cation to one adsorption center. With the carbonate-calcium composition of groundwater, the divalent cation of calcium will be the cation. The adsorption of calcium cations leads to recharge of theactive centers and the entire clay particle. As a result of these geochemical processes, large mineral particles turn out to be negatively charged, and colloidal clayey ones positively. The interaction of the electrostatic forces of these charges leads to the aleurite particles being clogged with thin clay covers. However, the tendency of the system to reduce free energy leads to the formation of a bilateral electrovalent bond and, as a result of its performance, there is a further increase in the thickness of the clay shells of mineral grains and the strong binding of the clay shirts of the adjoining grains. So complex soil aggregates are formed. Chemogenic calcite falling out of soil solutions also takes part in the formation of aggregates, cementing them or, in an early stage, covering the surfaces of fragments of mineral grains with films (Uhov et al., 2003).

In the conditions of Priobye, in the first, syngenetic, stage of loess formation, there are fine-grained covers of 
floodplain terraces of the $\mathrm{r}$. $\mathrm{Ob}$ and its tributaries, sandy manes in Kulunda barely covered with a thin soil-sod cover. In the syngenetic stage of development are eluvial loamy formations on the slopes of individual Paleozoic rocks, on watersheds and other positive elements of the relief.

All these modern surface formations that are heterogeneous in granulometric and mineralogical composition are characterized by friability of composition, high compressibility under loads, the absence of cementation structures, an insignificant content of calcium and magnesium carbonates, and low power (Yurchenko \& Budikova, 2008). These fine-earth formations cannot yet be called loess since they do not have the characteristic structure and other features of these rocks. It is only a forming fine-grained, silty sediment, drift, loose loamy or sandy eluvium or diluvium.

\section{Secondary stage of loess formation:}

The second stage of the loess formation usually referred as epigenetic. It begins after the drainage of precipitation of water-accumulative plains and floodplains transformation into terraces above the floodplain, with the beginning of soil cover formation on fine-earth sediments of various genetic types (Uhov et al., 2003). This stage of sediments diagenesis takes place under the influence of exogenous processes in the surface zone of weathering and soil formation, in the conditions of the podzolic zone, in the free aeration zone, above the groundwater level, an arid climate and deficit of precipitation. The main properties for the formation of the loess are aggregates, porosity, structure, and mechanical strength associated with this stage. The strength properties of clay rocks generally do not appear because of geological consolidation under the influence of the weight of the overlying strata, but as a result of internal physicochemical processes and in particular the aging of colloids. The diagenesis of sediments at this stage begins with a sharp decrease in the degree of humidity, general dehydration of fine soil, an increase in the salinity of ground solutions, an increase in the $\mathrm{HCO}_{3}$ content. In the initial period of this stage, the chemical weathering of sediments and, in the first place, feldspar as little stable in an acidic medium, is occurred, but with increasing $\mathrm{pH}$, this process slows down (Zhou et al., 1999). Probably, the processes of weathering of feldspars and other aluminosilicates are associated with the accumulation of silica in the sediment. It is believed that in podzolic soils silica is accumulated largely due to the needles of spruce. As studies have shown, from plant residues in the form of phytolitharia and silicified tissues, up to $40-60 \mathrm{~kg}$ per hectare of silica, which passes through the form of opal-chalcedony and turns into secondary quartz, annually gets into the soil. But favorable conditions for the formation of secondary quartz are created only in a neutral or weakly acidic medium, that is, at the beginning of the second stage of forest formation. However, geochemical processes occurring in the sediment gradually lead to an increase in the $\mathrm{pH}$ of the medium to neutral and slightly alkaline. In this regard, begins the accumulation of oxides of alkali and alkaline-earth elements. Amorphous Ferrum sesquihydrate, formed during precipitation weathering, paint the rock yellowish-fawn or grayish-fawn. With a decrease in humidity from the solution of film and capillary water, a number of salts fall out and coagulation of colloidal components occurs. $\mathrm{Ca}\left(\mathrm{HCO}_{3}\right)_{2}, \mathrm{Fe}(\mathrm{OH})_{3}$, and $\mathrm{CaSO}_{4} \cdot 2 \mathrm{H}_{2} \mathrm{O}$ are first precipitated and partially crystallized. Ferrum hydroxide, as it dehydrates, passes into limonite, which, on larger particles, in the root hair passages, forms colloidal films in the pores, and shell-like incrustations (Zhou \& Shackleton, 1999). In the process of compaction and dehydration, some components of the solid phase of precipitation will recrystallize. In addition to the molecular bonds that have taken place in the accumulating sediment, as the colloids age and as pore water evaporates, crystallization bonds begin to form. In the surface zone of precipitation, the evaporation zone, a large activity belongs to carbon dioxide. The deposited material undergoes intensive weathering, which is expressed not only in the kaolinization of feldspar, as mentioned above, but especially in the removal of chlorides and sulfates and in enrichment with carbonates, both due to the minerals weathering of the drill itself and due to the inflow of carbonates with groundwater. This phase proceeds against the background of soil formation, against the background of organic substances accumulation in fine-grained surface formations (Spassov et al., 2003).

With the increase in the thickness of the forming rock due to the accumulation of sediments from above in its lower zones, the role of silicic acid and sesquioxides in cementation and hardening of internal bonds, increasing the strength and stability of the structure, grows (Efimova et al., 2003). The structure of such loess-like loams is more durable than the structure of loams overlapping them, in which carbonated lime, as a cementing substance, plays a large role in comparison with Ferrum hydroxides.

Loess-like loams and sandy loams that make up the covers of the Priobsky plateau are mainly in the epigenetic stage of their development. In the lower horizons of the loess rocks of the Red-Dubrovinsk suite (Q2' - Q22), this process is closer to the completion of the second stage of loess formation, whereas in the upper zones, in the covers, eluvial and soil processes still occur. The greatest macroporosity, under-compaction, high compressibility under load, subsidence - all this is characteristic of loess rocks that are in the first phase of the epigenetic stage development. If during its initial period only coagulation and crystallization bonds arise in loess rocks, by the end of the stage they predominate in the rock and determine the stability of the aggregates' structures.

The third stage in the existence of loess rocks is 


\section{GENERAL ARTICLE}

metagenetic. This stage of degradation of the loess traits of the rock, its unloessivation, loess transformation into compacted loams and clays, into marlites (Yurchenko \& Budikova, 2008).

While increasing humidity in depressions and hollows, forest vegetation begins to develop, the groundwater level rises, the degradation of loess rocks develops with the formation of an illuvial horizon and upper watering on it. Carbonates are removed from the loess rock, calcium and magnesium are displaced from the exchangeable cations, and signs of unsaturation appear. In the steppe regions, the loess from the surface is leached and transformed into powerful dark-colored, black-earth-like soils (Uhov et al., 2003). With a decrease, and especially with the termination, of drainage in the rock, the process of salinization develops. In this stage, the migration of highly mobile anions $\mathrm{SO}_{4}$ ", $\mathrm{Cl}$ 'and easily soluble carbonates is usual. The $\mathrm{pH}$ value of the medium increases. All this is accompanied by the destruction of aggregates, rock structure and loss of loess properties of the rock in general. Amorphous silica dioxide accumulated in slightly acidic and neutral medium conditions, in alkaline conditions characteristic of the metagenetic stage, disappears from the rock (it is probably consumed during the synthesis of montmorilloniteand beidellite) or stabilizes.

In the lower horizons of loess rocks, if they are protected from precipitation and washing with groundwater, the signs of the former loess rock remain for a long time. Indeed high porosity, under-compaction, increased carbonate content, residual aggregation (Efimova et al., 2003). Silica sol is stable under acidic conditions, and in alkaline, it forms a gel. Since the silica soil is a negative colloid, then with the accumulation of calcium, magnesium, etc. cations in the ground solution, under conditions of a weakly alkaline medium with a weakly oxidizing potential, it coagulates and forms a strong rock structure (Spassov et al., 2003). Loess rock gradually loses its plastisity, stabilization and recrystallization of colloids occur, the rock acquires the properties of a semi-solid or solid body, the structural bonds of aggregates and micro aggregates are strengthened.

\section{Loss of loess properties of the rock:}

It can go in two ways; either as the destruction of aggregates, loess transformation into a dense silty clay or as colloids stabilization and recrystallization, hardening of the aggregates, the rock compaction, the change of its chemical and physical properties.

The process of diagenetic transformation of fine soil is inextricably linked with the process of sediment accumulation. In the southern regions of Siberia, loess strata, interbedded with unloessed sandy loams, are often observed. During periods of terraces drainage, drainage of the alluvial and foothill plains there was a redeeming of accumulated sediment. But as soon as the deposition of
Ambient Science, 2019: Vol. 06(1); 01-06 DOI:10.21276/ambi.2019.06.2.ga01

fine-grained soil, especially of coarse-grained matter, intensified, this process began to lag behind sedimentation, and the loessivation developed again only with a decrease in speed or with a complete cessation of sediment accumulation, provided that it was drained. In cases of accumulation of flood plain alluvium, periodically soaked and washed, some loess signs of such sediments appeared already during syngenetic processes in aeolian deluvial sediments, full formation of the rock structure was completed only in the epigenetic stage after the terraces and plains were completely drained.

Diagenetic processes that give loess form to finegrained sediments develop exclusively in the zone of winter freezing, in the zone of soil-forming processes development, under conditions where moisture evaporates over precipitates, in the aeration zone and penetrate the depth of not more than 5-8 m (Efimova et al., 2003).

\section{Conclusion:}

Consequently, the loess rocks of Siberia were formed by epigenetic sediments transformation of different origin. Syngenetic transformations of the sediments were subordinate, the loess structure was fully formed only in the second stage. The deluvium of slopes and eolian dust, with a continuous and long accumulation process, soon after accumulation or almost simultaneously with it, under certain climatic conditions, turn into a loess rock, i.e., with intensive weathering and a continuous soil-forming process (Yurchenko \& Budikova, 2008). The epigenetic stage of the loess formation, in this case, is superimposed on the syngenetic. In the aeolian and deluvial sediments of the arid steppes of semi-deserts, only weakly moistened with atmospheric precipitation, geochemical processes proceeded under conditions of a neutral or weakly alkaline environment. At the same time, accumulation of carbonates, oxides of alkalis and alkaline lands began simultaneously with sediments accumulation and the loessivation process proceeded relatively quickly. Diluvial and proluvial demolition were widely developed within a huge plume of weathering products that stretched along the foothills of the Altai, Salair and Kuznetsk Alatau (Uhov et al., 2003). Deluvial processes in these areas are widely developed in modern times.

The accumulation of aeolian dust, both of local origin and of the Kazakh dispersing hillocky area, occurred in all regions of Western Siberia, but especially dust accumulated within the foothill trail and steppe regions of the southern lowlands. The amount of dust-covered by grass is $1-3 \mathrm{~mm}$ annually. Judging by the lithological sections, the loess formation was often interrupted by the alluvial-proluvial coarser sediment and the overlapped loam or sandy loam overlapped with sands. But probably more often the loess structure formation of loam and sandy loam was completed under a thin cover forming soil or sediment of sand. 
Loess rock is the most dynamic and unstable system in which its constituent elements - mineral and particle size distribution, exchange bases, humidity, structure - are in constant and continuous communication with the surrounding physiographic environment. The final phase of such a system development in the formation cycle of sedimentary rocks is dense calcareous loam, clay, marlite, marl. The composition and properties of loess rocks are most susceptible to changes over time and therefore they are not found in sediments older than the lower Pleistocene.

\section{References:}

Efimova, M.R., Ganchenko, O.I. \& Petrova E.V., (2003): Praktikum Po Obshchej Teorii Statistiki, pp 14-22. Pub. by: Finansyi Statistika, Moscow. p. 368.

Spassov, S., Heller, F., Evans, M.E., Yue, L.P. \& von Dobeneck, T., (2003): A lock-in model for the complex Matuyama-Brunhes boundary record of the loess/palaeosol sequence at Lingtai (Central Chinese Loess Plateau). Geophys. J. Int., 155:350-366.
Uhov, S.B., Semyonov, V.V., Znamenskij, V.V. (2002): Mekhanika gruntov, osnovaniya i fundamenty, Vysshaya shkola, 254(4):46-52.

Yurchenko, S.G. \& Budikova, A.M. (2008): Metodika rascheta ozhidaemoj sovmestnoj prosadochnoj deformacii gidrotekhnicheskih sooruzhenij i ih lyossovyh osnovanij s uchetom oblastizamachivaniya. Vestnik Tomskogo gosudarstvennogo arhitekturno-stroitel'nogo universiteta, 19(2):20-35.

Zhou, L.P. \& Shackleton, N. (1999): Misleading positions of geomagnetic reversal boundaries in Eurasian loess and implications for correlation between continental and marine sedimentary sequences, Earth Planet. $\underline{\text { Sci. Letters, }}$ 168(1-2):117-130. 